\begin{tabular}{|l|l|l||}
\hline \multicolumn{2}{|c|}{ PublisherInfo } \\
\hline \hline PublisherName & $:$ & BioMed Central \\
\hline \hline PublisherLocation & $:$ & London \\
\hline \hline PublisherImprintName & $:$ & BioMed Central \\
\hline \hline
\end{tabular}

\title{
Modulation of angiogenesis by VEGF and placental growth factor
}

\begin{tabular}{||l|l||l||}
\hline \multicolumn{2}{|c||}{ ArticleInfo } \\
\hline \hline ArticleID & $:$ & 258 \\
\hline \hline ArticleDOI & $:$ & $10.1186 /$ ar-2002-77359 \\
\hline \hline ArticleCitationID & $:$ & 77359 \\
\hline \hline ArticleSequenceNumber & $:$ & 11 \\
\hline \hline ArticleCategory & $:$ & Paper Report \\
\hline \hline ArticleFirstPage & $:$ & 1 \\
\hline \hline ArticleLastPage & $:$ & 3 \\
\hline \hline & & RegistrationDate : 2002-7-8 \\
ArticleHistory & $:$ & Received \\
\hline \hline ArticleCopyright & $:$ 2002-7-8 \\
\hline \hline ArticleGrants & $:$ & Biomed Central Ltd2002 \\
\hline \hline
\end{tabular}




\begin{tabular}{|l|l|l||}
\hline ArticleContext & $:$ & 130754411 \\
\hline
\end{tabular}

Ewa Paleolog, ${ }^{\text {Aff1 }}$

Aff1 Kennedy Institute of Rheumatology, London, UK

\section{Keywords}

angiogenesis

\section{Context}

Formation of new blood vessels ('angiogenesis') is central to the development of rheumatoid arthritis (RA), to supply nutrients and oxygen to the synovium. An understanding of angiogenesis is thus useful for the development of vascular targeted therapies for treatment of RA. This study assessed the role of placental growth factor (PlGF) and its receptor Flt1, which also binds the angiogenic factor VEGF (vascular endothelial growth factor).

\section{Significant findings}

PIGF and VEGF stimulated growth of new vessels in a mouse model of ischemic myocardial revascularisation. Human PlGF also significantly increased formation of collateral branches, following femoral artery ligation. Adenoviral transfer of PlGF into the skin of mouse ears caused formation of mature vessels, unlike VEGF, which leads to oedema and growth of unstable vascular structures. AntiFlt-1 antibody inhibited vascularisation and growth of human tumours in nude mice, and reduced the size and growth of plaques in atherosclerosis-susceptible apolipoprotein-E-deficient mice. However, anti-Flt-1 failed to affect angiogenesis in the plaque and in the adventitia. More likely, in this model, anti-Flt-1 reduced inflammation by decreasing macrophage infiltration. Finally, anti-Flt-1 reduced the incidence of joint disease and development of clinical symptoms in the mouse collagen-induced arthritis model. Synovial infiltration by inflammatory cells and angiogenesis were reduced by anti-Flt-1.

\section{Comments}


Firstly, the authors compared the effects of PIGF and VEGF, in the context of their therapeutic potential in promoting angiogenesis. Therapeutic angiogenesis using VEGF has been promoted for the treatment of patients with myocardial and critical limb ischemia. However VEGF treatment may promote formation of immature unstable blood vessels and/or oedema, and further studies are required to determine the optimal formulation and combination of growth factors. This report suggests that PlGF should be considered, in addition to VEGF and fibroblast growth factor (FGF). Conversely, anti-Flt-1 was effective in several models associated with excess angiogenesis - tumours, arthritis, and atherosclerosis. The role of Flt-1 has remained enigmatic, and it is generally though that Flt-1 functions as a non-signalling 'reservoir' for VEGF. This has driven research into angiogenesis inhibitors to focus primarily on Flk-1. However, the present study implies that in angiogenesis-dependent conditions associated with inflammation - of which RA is an example - inhibition of Flt-1 could be considered.

\section{Methods}

Mouse models of angiogenesis (Matrigel and corneal micropocket assays), atherosclerosis (ApoE -/-) and collagen-induced arthritis . Transplantation of bone marrow, transduced with a green fluorescent protein-expressing vector. Adenoviral gene transfer of PlGF. Mouse models of myocardial and limb ischemia.

\section{References}

1. Luttun A, Tjwa M, Moons L, Wu Y, Angelillo-Scherrer A, Liao F, Nagy JA, Hooper A, Priller J, De Klerck B, Compernolle V, Daci E, Bohlen P, Dewerchin M, Herbert JM, Fava R, Matthys P, Carmeliet G, Collen D, Dvorak HF, Hicklin DJ, Carmeliet P: Revascularization of ischemic tissues by P1GF treatment, and inhibition of tumor angiogenesis, arthritis and atherosclerosis by anti-Flt1. Nat Med . 2002, 8: (epub ahead of print - doi:10.1038/nm731) .

This PDF file was created after publication. 